\title{
Afgestudeerden van Zuyd Hogeschool en Universiteit Maastricht: Hun oriëntatie op een loopbaan in Maastricht en omgeving
}

Citation for published version (APA):

Allen, J., Cörvers, F., \& Smeets, C. (2021). Afgestudeerden van Zuyd Hogeschool en Universiteit Maastricht: Hun oriëntatie op een loopbaan in Maastricht en omgeving. ROA. ROA Reports No. 006 https://doi.org/10.26481/umarep.2021006

Document status and date:

Published: 21/10/2021

DOI:

10.26481/umarep.2021006

Document Version:

Publisher's PDF, also known as Version of record

Please check the document version of this publication:

- A submitted manuscript is the version of the article upon submission and before peer-review. There can be important differences between the submitted version and the official published version of record.

People interested in the research are advised to contact the author for the final version of the publication, or visit the DOI to the publisher's website.

- The final author version and the galley proof are versions of the publication after peer review.

- The final published version features the final layout of the paper including the volume, issue and page numbers.

Link to publication

\footnotetext{
General rights rights.

- You may freely distribute the URL identifying the publication in the public portal. please follow below link for the End User Agreement:

www.umlib.nl/taverne-license

Take down policy

If you believe that this document breaches copyright please contact us at:

repository@maastrichtuniversity.nl

providing details and we will investigate your claim.
}

Copyright and moral rights for the publications made accessible in the public portal are retained by the authors and/or other copyright owners and it is a condition of accessing publications that users recognise and abide by the legal requirements associated with these

- Users may download and print one copy of any publication from the public portal for the purpose of private study or research.

- You may not further distribute the material or use it for any profit-making activity or commercial gain

If the publication is distributed under the terms of Article $25 \mathrm{fa}$ of the Dutch Copyright Act, indicated by the "Taverne" license above, 
Maastricht University

\section{Afgestudeerden van Zuyd Hogeschool en Universiteit Maastricht: Hun oriëntatie op een loopbaan in Maastricht en omgeving}

Jim Allen

Frank Cörvers

Chayenne Smeets

\section{ROA Rapport}

ROA-R-2021/6

Researchcentrum voor Onderwijs en Arbeidsmarkt | ROA Research Centre for Education and the Labour Market / ROA 


\title{
Colofon
}

(c) Researchcentrum voor Onderwijs en Arbeidsmarkt (ROA). Niets uit deze uitgave mag op enige manier worden verveelvoudigd zonder voorafgaande schriftelijke toestemming van de directeur van het ROA.

\author{
Researchcentrum voor Onderwijs en Arbeidsmarkt \\ Postbus 616 \\ 6200 MD Maastricht \\ $\mathrm{T}+31433883647$ \\ $\mathrm{F}+31433884914$ \\ secretary-roa-sbe@maastrichtuniversity.nl \\ www.roa.nl \\ School of Business and Economics \\ Maastricht University \\ Vormgeving \\ ROA secretariaat, Maastricht
}

ISBN: 978-90-5321-601-9

ISSN: 2666-8858

september 2021 


\section{Inhoud}

1 Inleiding

2 Waarom recent afgestudeerden in hun studiestad blijven werken of niet

3 Verschillen naar herkomstregio en opleidingssector 9 3.1 Verschillen naar herkomstregio 9

3.2 Verschillen naar opleidingssector 10

3.3 Verschillen naar studiestad (alleen voor Zuyd Hogeschool) 11

4 Conclusie $\quad 13$

Literatuur 


\section{Voorwoord}

Dit rapport gaat in het bijzonder over de oriëntatie op de loopbaan van pas afgestudeerden van Zuyd Hogeschool en Universiteit Maastricht. Het onderzoek is uitgevoerd in opdracht van de Gemeente Maastricht, in aanvulling op de analyses van de Buurtmonitor voor Maastricht. De Buurtmonitor zegt vooral iets over 'het thuisvoelen' van de inwoners van Maastricht, maar uiteraard minder over de mate waarin studenten hun loopbaan willen vervolgen in de regio van hun alma mater. Eerder onderzoek over vestiging en vertrek in opdracht van de Gemeente Maastricht (Hooijen en Cörvers, 2019) ging over de verhuismobiliteit in Maastricht en vergelijkbare steden. 


\section{Resumé}

In dit rapport wordt verslag gedaan van een onderzoek naar de mate waarin studenten van Zuyd Hogeschool en Universiteit Maastricht zich oriënteren op een carrière in de stad waar ze gestudeerd hebben. Daartoe is er eind 2020 een enquête uitgezet onder hbo- en wo-afgestudeerden van Zuyd Hogeschool en Universiteit Maastricht. Het doel van de enquête was om te onderzoeken of schoolverlaters wel of niet in dezelfde stad werkzaam zijn als waar ze hebben gestudeerd, en om de factoren na te gaan die bij deze keuze een rol hebben gespeeld. De vragen van de enquête richten zich op de verschillende redenen om in de studiestad te blijven werken, of om juist werk aan te nemen in een andere stad dan waar men gestudeerd heeft. Ook is er gekeken naar activiteiten die mogelijk van invloed zijn geweest op de interesse van studenten om in de studiestad te blijven werken.

De belangrijkste bevindingen zijn:

- Slechts $16 \%$ van de afgestudeerden van Zuyd Hogeschool en $17 \%$ van de afgestudeerden van Universiteit Maastricht besloot te blijven werken in de stad waar ze hebben gestudeerd. Dit percentage is veel hoger onder afgestudeerden van de UM die al op 16-jarige leeftijd in Limburg woonden (34\%). Dit verschilt ook naar opleidingssector, waarbij afgestudeerden kunst (30\%) en bètatechniek (20\%) van Zuyd, en afgestudeerden gezondheidszorg (20\%) van de UM het vaakst in hun studiestad zijn blijven werken.

- Van de activiteiten waaraan men kon meedoen tijdens de studie bleken vooral stages de interesse te hebben vergroot om in de studiestad te blijven werken. Ongeveer twee op de vijf afgestudeerden van beide instellingen die in hun studiestad bleven werken gaven aan dat hun interesse hierdoor was vergroot.

- Andere activiteiten tijdens de studie bleken meer van invloed te zijn op afgestudeerden van de Universiteit Maastricht dan op afgestudeerden van Zuyd Hogeschool. Zo gaf circa een derde van de afgestudeerden van de UM aan dat hun interesse in een baan in de studiestad was vergroot door informatie over de werkgelegenheid, over onderzoek en/of opdrachten voor bedrijven en organisaties en over netwerkactiviteiten. Onder afgestudeerden van Zuyd lagen deze percentages onder de $20 \%$.

- Ook wanneer men niet in de studiestad is blijven werken, zien we dat UM-afgestudeerden meer het belang inzien van het organiseren van allerlei lokale activiteiten als manier om hun interesse in een baan in de studiestad te vergroten dan afgestudeerden van Zuyd. Vooral stages (UM: 75\%; Zuyd 70\%), informatie over 
beschikbare werkgelegenheid (UM: 72\%; Zuyd 66\%), onderzoek of opdrachten voor bedrijven en organisaties (UM: 68\%; Zuyd 55\%), netwerkactiviteiten (UM: 65\%; Zuyd 49\%) en careerevents (UM: 62\%; Zuyd 45\%) worden als kansrijke activiteiten gezien.

- $\quad$ De keuze om niet in de studiestad te blijven werken is vaak gebaseerd op de perceptie van betere baankansen elders (UM: 55\%; Zuyd 44\%), en in mindere mate door het feit dat velen al van tevoren de intentie hadden om terug te gaan naar de regio waar ze voorafgaand aan de opleiding woonden (UM: 23\%; Zuyd 29\%), de wens om dichter bij familie en/of vrienden te zijn (beide instellingen $20 \%$ ), de werksituatie van de partner (UM: 17\%; Zuyd 11\%), de wens om de eigen horizon te verbreden (UM: 15\%; Zuyd 14\%) en het feit dat ze de studiestad geen fijne stad vonden om te werken (UM: 9\%; Zuyd 15\%).

- $\quad$ De keuze om wel in de studiestad te blijven werken was beduidend minder vaak gebaseerd op gepercipierde baankansen (UM: 18\%; Zuyd 4\%), maar juist vaak op de band die men met de regio voelt. Zo gaf ongeveer drie op de tien afgestudeerden van beide instellingen aan dat ze van tevoren al de intentie hadden om te blijven studeren en werken in de regio waar ze zijn opgegroeid; ook bekendheid met de omgeving (beide instellingen 29\%) en de aanwezigheid van familie en vrienden in de regio (UM: 26\%; Zuyd 23\%) werden vaak belangrijk gevonden. Vooral voor de afgestudeerden van de UM komt daar nog bij dat hun partner in de regio werkt ( $28 \%$, tegenover $18 \%$ onder afgestudeerden van Zuyd), en dat ze bekend zijn met de plaatselijke taal (19\% UM, tegenover $11 \%$ Zuyd) en cultuur (22\% UM, tegenover $8 \%$ Zuyd).

- $\quad$ Ervaringen tijdens de studie en specifieke kenmerken van het professionele en privéleven lijken over het algemeen een sterkere invloed te hebben op de keuze van de werklocatie onder afgestudeerden die voorafgaand aan de studie buiten Limburg woonden dan onder afgestudeerden die vóór de studie al in Limburg woonden. Afgestudeerden die uit andere regio's komen zijn meer ontvankelijk voor activiteiten zoals netwerkactiviteiten, careerevents en bestuursactiviteiten tijdens de studie als mogelijke manieren om hen meer aan de studiestad te binden. Tegelijktijd blijken ze relatief vaak elders te gaan werken vanwege de werksituatie van de partner, en relaties met familie en vrienden. Wel blijven ze vaker in de studiestad werken vanwege de werksituatie van de partner en vanwege hun eigen baankansen. Afgestudeerden afkomstig uit Limburg blijven relatief vaak in de studiestad vanwege de band met familie en vrienden, en met de intentie vooraf om in de regio te blijven waar men is opgegroeid.

- Voor afgestudeerden van economische opleidingen lijkt het besluit om wel of niet in de studiestad te blijven werken vaak een relatief zakelijke kwestie. Ze lijken gevoelig te zijn voor allerlei activiteiten tijdens de studie zoals netwerk- en careeractiviteiten, en baseren hun keuze relatief vaak op baankansen.

- Voor afgestudeerden van gezondheidszorgopleidingen lijken zakelijke overwegingen gemengd te zijn met meer maatschappelijke en persoonlijke overwegingen. Zo lijken ze ontvankelijk te zijn voor activiteiten zoals vrijwilligerswerk 
tijdens de studie, en baseren ze hun feitelijke mobiliteitsbesluit vaak op zaken als banden met familie en vrienden en de mate waarin ze in de regio zijn ingebed.

- Afgestudeerden van de sectoren kunst en bètatechniek van Zuyd Hogeschool geven aan vaak gevoelig te zijn voor opdrachten voor plaatselijke bedrijven of organisaties, wat een manier kan zijn om hun interesse om te blijven in de studiestad positief te beïnvloeden.

- Afgestudeerden van de sector gedrag en maatschappij van de UM lijken in veel opzichten op afgestudeerden van gezondheidszorgopleidingen, in de zin dat ze zakelijke overwegingen combineren met maatschappelijke en persoonlijke overwegingen.

- Afgestudeerden van een Maastricht-locatie van Zuyd Hogeschool blijken relatief ontvankelijk te zijn voor netwerk- en careeractiviteiten tijdens de studie, en hun feitelijke keuzes vaak te baseren op de band die ze met de stad al hadden en/of tijdens de studie hebben opgebouwd.

- Afgestudeerden van Zuyd Hogeschool uit de stad Heerlen nemen relatief vaak een baan elders aan door onbekendheid met wet- en regelgeving en de mening dat de studiestad geen fijne stad is om te werken.

- Afgestudeerden van Zuyd Hogeschool uit Sittard-Geleen lijken weinig ontvankelijk voor ervaringen tijdens de studie, en noemen relatief vaak de band met familie en vrienden en de bekendheid met de wet- en regelgeving als reden om te blijven werken in hun studiestad. 



\section{Inleiding}

In dit rapport wordt verslag gedaan van een onderzoek naar de mate waarin studenten van Zuyd Hogeschool en Universiteit Maastricht zich oriënteren op een carrière in de stad en of regio. Dit onderzoek is uitgevoerd in opdracht van de Gemeente Maastricht, in aanvulling op de analyses van de Buurtmonitor 2018 voor Maastricht. Die zegt vooral iets over 'het thuisvoelen' van de inwoners van Maastricht, maar vanzelfsprekend minder over de mate waarin studenten hun loopbaan willen vervolgen in de regio van hun alma mater.

De Gemeente Maastricht heeft de volgende hoofdvragen geformuleerd voor het onderzoek onder afgestudeerden:

\section{Heeft u zich georiënteerd op loopbaanmogelijkheden in de stad en/of (Eu) regio?}

1. Zo ja: Welke activiteiten hebben het meest bijgedragen aan de oriëntatie op uw loopbaan in de stad en of regio?

2. Zo nee: Wat zou voor u de beste manier zijn geweest om u meer te oriënteren op een loopbaan in de stad en/of regio?

Dit rapport gaat vooral over de oriëntatie op de loopbaan van pas afgestudeerden van Zuyd Hogeschool en Universiteit Maastricht. Eerder onderzoek over vestiging en vertrek in opdracht van de Gemeente Maastricht (Hooijen en Cörvers, 2019) laat zien dat er twee pieken zijn in verhuismobiliteit die typisch zijn voor studentensteden. De eerste piek betreft de hoge instroom van jongeren van 20 jaar, welke samenhangt met het studeren in Maastricht. De tweede piek kenmerkt zich door een vertrek uit Maastricht na afloop van de studie. Vergeleken met (perifere) steden zonder grote universiteiten scoren Maastricht en Groningen goed op het vasthouden van universitair opgeleiden. Van degenen geboren in 1979 en op 35-jarige leeftijd woonachtig in Maastricht of Groningen, heeft zo'n 20\% minimaal een master-diploma. In Leeuwarden en Assen, Heerlen en Sittard-Geleen is dat slechts $5 \%$.

Uiteraard hangt de keuze voor de woonlocatie (i.e. de verhuisbeslissing) samen met de keuze voor de werklocatie. Er is daarbij sprake van wederzijdse beïnvloeding. Uit de literatuur blijken verschillende factoren van belang te zijn voor het besluit van (jonge) mensen om wel of niet te verhuizen. Uitgangspunt in de literatuur is meestal het neoklassieke economische model, dat uitgaat van push- en pull factoren (De Hoon \& Cörvers, 
2016). Push factoren zijn factoren die ervoor zorgen dat pas afgestudeerden uit de regio wegtrekken. Pull factoren zijn de aantrekkingsfactoren van een regio die ervoor zorgen dat afgestudeerden naar de regio toekomen. Hierbij kan men onderscheid maken tussen harde en zachte factoren. Harde factoren zijn werkgerelateerd, zoals meer baankansen of een hoger inkomen in vergelijking met een andere regio (Harris en Todaro, 1970). ' Zachte factoren zijn gerelateerd aan de kwaliteit van leven in de stad of regio in vergelijking met wat elders wordt verwacht (Williams en Sofranko, 1979). Het nieuw economisch model voegt hieraan toe dat het verhuizen naar een andere stad of regio ook een beslissing is die gezamenlijk met meerdere personen, dus op collectief niveau, wordt genomen (De Hoon \& Cörvers, 2016). De partner maar ook bredere relaties met familie en vrienden kunnen daarbij een rol spelen.

In dit rapport gaat het doorgaans de mobiliteitsbeslissingen van personen die aan het begin van hun beroepsloopbaan staan, namelijk de pas afgestudeerden van het hoger onderwijs. Het roltrapmodel (Fielding ,1992) geeft aan dat jonge mensen die aan het begin van hun carrière staan vaak naar stedelijke gebieden trekken omdat ze daar meer baankansen hebben dan in de niet-stedelijke gebieden. Mogelijk zullen ze ten tijde van hun pensioen terugverhuizen naar de regio waar zij oorspronkelijk vandaan komen, maar die stap is hier niet aan de orde.

De nationale politiek en de landelijke media kunnen een rol spelen in de beïnvloeding van pas afgestudeerden om weg te trekken naar de Randstad (Cörvers, 2019). Deze suggereren kunnen bijvoorbeeld een beeld scheppen dat er alleen in de Randstad, als centrum van het maatschappelijke, politieke en economische leven, goede baankansen zijn. Mensen kunnen zich soms meer door zulke beeldvorming laten leiden dan door de werkelijke kansen. Meier, Reverda en Van der Wouw (2015) geven met het begrip "Randland" aan dat lang niet alles buiten de Randstad als platteland is te bestempelen, en dat in deze gebieden ook innovatieve ontwikkelingen plaatsvinden die nieuwe bedrijvigheid teweeg kunnen brengen. In de beeldvorming kan dit worden verdrongen door de dominantie van de Randstad. Cörvers (2019) geeft aan hoe jongeren toch in de regio kunnen worden gehouden door onder andere het aanbieden van stageplaatsen en het spreiden van opleidingsfaciliteiten, en door specifieke opleidingen aan te bieden die gewenst zijn in de regio.

Om nader te onderzoeken hoe jongeren behouden kunnen worden voor de eigen stad en regio, is er eind 2020 een enquête uitgezet onder hbo- en wo-afgestudeerden van Zuyd Hogeschool en Universiteit Maastricht, in aansluiting op respectievelijk de landelijke HBO-Monitor (www.hbomonitor.nl) en de Nationale Alumni Enquête (NAE, www. vsnu.nl/nl NL/nae.html). Het betrof hier respondenten van het afstudeerjaar 2018/19, die naar keuze een vragenlijst in het Nederlands of Engels konden invullen. Het doel was om te onderzoeken of schoolverlaters wel of niet in dezelfde stad werkzaam zijn als waar ze hebben gestudeerd, en welke factoren bij deze keuze een rol hebben gespeeld. De

1 Zie ook Hooijen en Cörvers (2019) voor een inventarisatie van de harde en zachte factoren die van belang zijn voor de verhuisbeslissingen in de Euregio. 
vragen van de enquête richten zich op de verschillende redenen om in de stad te blijven werken, of om juist werk aan te nemen in een andere stad dan waar men gestudeerd heeft. Ook is er gekeken naar activiteiten die mogelijk van invloed zijn geweest op de interesse van studenten om in de studiestad te blijven werken.

In totaal is de enquête ingevuld door 1.676 afgestudeerden, waarvan 923 van Zuyd Hogeschool (respons: 35,8\%) en 753 van Universiteit Maastricht (respons: 31,7\%). Van de afgestudeerden van Zuyd Hogeschool heeft ongeveer 45\% in Heerlen gestudeerd, 29\% in Maastricht en $26 \%$ in Sittard-Geleen. Bij Zuyd Hogeschool zijn de meeste mensen afgestudeerd in de sectoren economie (45\%), bètatechniek (20\%) en gezondheidszorg $(19 \%)$, met kleinere groepen afgestudeerden uit de sectoren kunst (9\%), sociale studies (5\%) en onderwijs (2\%). De grootste groepen afgestudeerden van Universiteit Maastricht zien we bij de sectoren gezondheidszorg (34\%), economie en gedrag en maatschappij (beiden $21 \%$ ) en recht (15\%), met kleinere aantallen voor de sectoren natuurwetenschapen (7\%) en taal en cultuur (3\%). In dit rapport worden de gegevens uit de enquête geanalyseerd met als doel antwoord te krijgen op de bovengestelde vragen.

In paragraaf 2 wordt ingegaan op de enquêteresultaten voor de Zuyd Hogeschool en de Universiteit Maastricht als geheel. Paragraaf 3 laat zien op welke punten deelpopulaties binnen deze instellingen afwijken van het algemene beeld. In het bijzonder wordt hierbij gekeken naar verschillen naar herkomstregio, opleidingssector en - enkel voor Zuyd Hogeschool - studiestad. In paragraaf 4 worden ten slotte de belangrijkste conclusies van het onderzoek op een rij gezet. 



\section{Waarom recent afgestudeerden in hun studiestad blijven werken of niet}

In deze paragraaf worden de uitkomsten geanalyseerd voor Zuyd Hogeschool en Universiteit Maastricht als geheel. Eerst kijken we in tabel 1 naar de feitelijke mobiliteit van afgestudeerden van de twee instellingen, en zetten dit af tegen de interesses en intenties die ze tijdens de studie hadden. De tabel laat zien dat slechts weinig afgestudeerden van Zuyd Hogeschool (15,5\%) en Universiteit Maastricht (17,4\%) momenteel werkzaam zijn in de stad waar ze hebben gestudeerd. Hiervan was iets meer dan een derde $(33,3 \%)$ van de afgestudeerden van Zuyd Hogeschool en ruim de helft $(56,3 \%)$ de afgestudeerden van Maastricht al tijdens het afstuderen geïnteresseerd in een baan in de stad waar ze hebben gestudeerd. Driekwart van de afgestudeerden die in hun studiestad werken was tijdens de studie vooral op een baan in Nederland gericht. Onder afgestudeerden van Zuyd Hogeschool die in een andere stad zijn gaan werken had 30,2\% al tijdens de studie de interesse om in die specifieke stad te gaan werken, Onder afgestudeerden van Universiteit Maastricht die elders zijn gaan werken lag dit percentage iets hoger (32,7\%). Van de afgestudeerden van Zuyd Hogeschool die buiten hun studiestad zijn gaan werken, was driekwart vooral op een baan in Nederland in plaats van het buitenland gericht; dat is even vaak als onder afgestudeerden die in hun studiestad zijn gebleven. Bij de UM is dit aandeel onder afgestudeerden werkzaam buiten hun studiestad een stuk lager, iets minder dan drie op de vijf. Afgestudeerden van de UM hadden derhalve vaker interesse om te werken in het buitenland in plaats van Nederland.

Tabel 1

Werklocatie en intenties

\begin{tabular}{|l|r|r|}
\hline Afgestudeerden werkzaam in de studiestad & $\begin{array}{r}\text { Zuyd } \\
\text { Hogeschool }\end{array}$ & $\begin{array}{r}\text { Universiteit } \\
\text { Maastricht }\end{array}$ \\
\hline al tijdens de studie geïnteresseerd in werk in deze stad & $15,5 \%$ & $17,4 \%$ \\
\hline tijdens de studie geïnteresseerd in werk in Nederland & $33,3 \%$ & $56,3 \%$ \\
\hline & $74,7 \%$ & $74,4 \%$ \\
\hline Afgestudeerden werkzaam in andere stad & & \\
\hline al tijdens de studie geïnteresseerd in werk in deze stad & $84,5 \%$ & $82,6 \%$ \\
\hline tijdens de studie geïnteresseerd in werk in Nederland & $30,2 \%$ & $32,7 \%$ \\
\hline
\end{tabular}

Noot ${ }^{*}$ : percentage antwoorden 4 of 5 op 5-puntsschaal, van 1 "helemaal niet" tot 5 "in sterke mate".

Voor de beleidsmakers en werkgevers is het interessant om te weten waarom afgestudeerden de keuze maken om in de studiestad te blijven. In de enquête is daarom de vraag gesteld welke activiteiten de interesse van de toenmalige studenten hebben vergroot 
in een baan in de stad waar ze momenteel werken. Tabel 2 toont de antwoorden van afgestudeerden die in hun studiestad zijn gaan werken.

Wat opvalt is dat ongeveer vier op de tien afgestudeerden van beide onderwijsinstellingen stages als belangrijke activiteit hebben genoemd. Wat verder opvalt is dat de meeste andere activiteiten veel meer van invloed waren op de voorkeuren van afgestudeerden van Universiteit Maastricht dan op die van afgestudeerden van Zuyd Hogeschool. Zo geeft ongeveer en derde van de afgestudeerden van Universiteit Maastricht aan dat informatie over werkgelegenheid, onderzoek en/of opdrachten voor bedrijven en organisaties en netwerkactiviteiten belangrijk waren, tegen minder dan één op de vijf afgestudeerden van Zuyd Hogeschool. Andere belangrijke activiteiten tijdens de studie zijn onderzoek of opdrachten voor organisaties en netwerkactiviteiten.

\section{Tabel 2}

In hoeverre hebben de volgende activiteiten tijdens uw studie uw interesse vergroot in een baan in de stad waar u nu werkt? (voor afgestudeerden die in de studiestad zijn gebleven)

\begin{tabular}{|c|c|c|}
\hline & $\begin{array}{r}\text { Zuyd } \\
\text { Hogeschool }\end{array}$ & $\begin{array}{l}\text { Universiteit } \\
\text { Maastricht }\end{array}$ \\
\hline \multicolumn{3}{|l|}{ Activiteiten tijdens studie interesse vergroot ${ }^{*}$} \\
\hline Informatie over de beschikbare werkgelegenheid in bedrijven en organisaties & $18,8 \%$ & $30,1 \%$ \\
\hline Stages & $41,7 \%$ & $39,3 \%$ \\
\hline Onderzoek en/of opdrachten voor bedrijven en organisaties & $19,3 \%$ & $33,0 \%$ \\
\hline Vrijwilligerswerk & $2,8 \%$ & $9,0 \%$ \\
\hline Bestuursactiviteiten & $2,8 \%$ & $11,6 \%$ \\
\hline Netwerkactiviteiten & $17,0 \%$ & $32,7 \%$ \\
\hline Careerevents & $11,3 \%$ & $18,0 \%$ \\
\hline Anders & $1,6 \%$ & $0,6 \%$ \\
\hline
\end{tabular}

Noot ${ }^{*}$ : percentage antwoorden 4 of 5 op 5-puntsschaal, van 1 "helemaal niet" tot 5 "heel veel".

Tabel 3 laat zien dat de genoemde activiteiten maar voor een kleinen groep, 9,3\% van de afgestudeerden aan Zuyd Hogeschool en $17,7 \%$ van de afgestudeerden aan de UM, de voorkeur heeft veranderd.

\section{Tabel 3}

Voorkeur hierdoor veranderd? (voor afgestudeerden die in de studiestad zijn gebleven)

\begin{tabular}{l|r|r|} 
& $\begin{array}{r}\text { Zuyd } \\
\text { Hogeschool }\end{array}$ & $\begin{array}{r}\text { Universiteit } \\
\text { Maastricht }\end{array}$ \\
\hline $\begin{array}{l}\text { Voorkeur om al dan niet te blijven in de stad of regio war je bent } \\
\text { afgestudeerd hierdoor veranderd?* }\end{array}$ & $9,3 \%$ & $17,7 \%$ \\
\hline \begin{tabular}{l} 
Noot *: percentage antwoorden 4 of 5 op 5-puntsschaal, van 1 "helemaal niet" tot 5 "heel veel". \\
\hline
\end{tabular}
\end{tabular}


Het is verder van belang om zicht te krijgen op de vraag of afgestudeerden die buiten de studiestad zijn gaan werken, door bepaalde activiteiten over te halen zouden zijn geweest om toch in de stad te blijven. Daarom is aan deze groep gevraagd welke activiteiten goed zouden werken om de interesse voor een baan in de studiestad of -regio te vergroten. De antwoorden hierop zijn in tabel 4 samengevat. Hieruit blijkt dat stages weer het meest worden genoemd, maar dat er ook andere activiteiten van belang zijn als een potentiële goede manier om afgestudeerden te binden aan de regio. Zo wordt informatie over beschikbare werkgelegenheid en onderzoek of opdrachten voor bedrijven en organisaties door een duidelijke meerderheid van de afgestudeerden van beide instellingen genoemd. Ook netwerkactiviteiten en careerevents worden vaak als optie genoemd. Wat weer opvalt, is dat de afgestudeerden van Universiteit Maastricht op alle fronten vaker van mening zijn dat dergelijke activiteten een verschil kunnen maken.

\section{Tabel 4}

In hoeverre zijn de volgende activiteiten zijn volgens u tijdens een studie een goede manier om de interesse van studenten te vergroten in een baan in de stad of regio waar ze studeren? (voor afgestudeerden die niet in de studiestad zijn gebleven)

\begin{tabular}{|l|r|r|}
\hline \begin{tabular}{l|l} 
Activiteiten tijdens studie beste manier \\
Informatie over de beschikbare werkgelegenheid in bedrijven en organisaties
\end{tabular} & $\begin{array}{r}\text { Zuyd } \\
\text { Hogeschool }\end{array}$ & $\begin{array}{r}\text { Universiteit } \\
\text { Maastricht }\end{array}$ \\
\hline $\begin{array}{l}\text { Stages } \\
\text { Onderzoek en/of opdrachten voor bedrijven en organisaties }\end{array}$ & $65,5 \%$ & $72,3 \%$ \\
\hline Vrijwilligerswerk & $70,2 \%$ & $75,4 \%$ \\
\hline Bestuursactiviteiten & $55,2 \%$ & $68,3 \%$ \\
\hline Netwerkactiviteiten & $20,0 \%$ & $28,7 \%$ \\
\hline Careerevents & $20,1 \%$ & $22,2 \%$ \\
\hline Anders & $49,2 \%$ & $65,1 \%$ \\
\hline
\end{tabular}

Noot": percentage antwoorden 4 of 5 op 5 -puntsschaal, van 1 "helemaal niet" tot 5 "heel veel".

De volgende twee tabellen gaan dieper in op de redenen dat respondenten niet of juist wel in de stad werkzaam zijn waar ze hebben gestudeerd. Tabel 5 laat eerst de redenen zien waarom mensen niet in de studiestad zijn blijven werken. De voornaamste redenen dat afgestudeerden niet in de regio bleven is dat afgestudeerden betere baankansen elders hadden of dat ze van tevoren al de intentie hadden om terug te gaan naar de regio waar ze voorafgaand aan de studie woonden. Het grootste verschil tussen Zuyd Hogeschool en Universiteit Maastricht, is dat afgestudeerden aan de UM veel vaker als reden een "taalbarrière" noemden. Dit heeft waarschijnlijk te maken met het feit dat de UM over het algemeen meer internationale studenten aantrekt. 


\section{Tabel 5}

Reden niet werkzaam in stad gestudeerd (meerdere antwoorden mogelijk)

\begin{tabular}{|c|c|c|}
\hline & $\begin{array}{r}\text { Zuyd } \\
\text { Hogeschool }\end{array}$ & $\begin{array}{l}\text { Universiteit } \\
\text { Maastricht }\end{array}$ \\
\hline \multicolumn{3}{|l|}{ Reden niet werkzaam in stad gestudeerd } \\
\hline Ik had helemaal geen intentie om te gaan werken & $8,6 \%$ & $3,0 \%$ \\
\hline Betere baankansen of loopbaanmogelijkheden ergens anders & $44,3 \%$ & $55,1 \%$ \\
\hline $\begin{array}{l}\text { Ik had de intentie om terug te gaan naar de regio waar ik voorafgaand aan } \\
\text { mijn studie woonde }\end{array}$ & $29,2 \%$ & $23,4 \%$ \\
\hline Mijn (toenmalige) partner had destijds werk in een andere regio & $10,6 \%$ & $16,8 \%$ \\
\hline Mijn familie en/of vrienden woonden destijds in een andere regio & $19,8 \%$ & $19,6 \%$ \\
\hline Taalbarrière & $2,3 \%$ & $14,6 \%$ \\
\hline Verschil in cultuur & $6,9 \%$ & $5,8 \%$ \\
\hline Onbekendheid met wet- en regelgeving & $0,8 \%$ & $4,0 \%$ \\
\hline Verbreding van mijn horizon & $13,8 \%$ & $15,2 \%$ \\
\hline Ik vind deze studentenstad geen fijne stad om te werken & $15,4 \%$ & $9,0 \%$ \\
\hline Anders & $23,4 \%$ & $20,0 \%$ \\
\hline
\end{tabular}

Tabel 6 geeft aan welke redenen afgestudeerden noemden om wel in de studiestad te blijven werken. Ongeveer drie op de tien afgestudeerden gaf aan dat ze van tevoren al de intentie hadden om te blijven studeren en werken in de regio waar ze zijn opgegroeid. Andere belangrijke redenen voor afgestudeerden van zowel Zuyd als de UM zijn: familie en vrienden wonen in de regio en bekendheid met de omgeving. Vooral voor afgestudeerden van de UM komen daar nog bij dat hun partner in de regio werkt, en dat ze bekend zijn met de plaatselijke taal en cultuur.

\section{Tabel 6}

Reden werkzaam in stad gestudeerd (meerdere antwoorden mogelijk)

\begin{tabular}{|l|r|r|}
\hline Reden werkzaam in stad gestudeerd & $\begin{array}{r}\text { Zuyd } \\
\text { Hogeschool }\end{array}$ & $\begin{array}{r}\text { Universiteit } \\
\text { Maastricht }\end{array}$ \\
\hline Minder baankansen of loopbaanmogelijkheden ergens anders & \\
\hline Ik had de intentie om te blijven in de regio waar ik ben opgegroeid & $4,0 \%$ & $17,6 \%$ \\
\hline Mijn (toenmalige) partner had destijds werk in deze regio & $31,7 \%$ & $33,3 \%$ \\
\hline Mijn familie en/of vrienden woonden destijds in deze regio & $17,8 \%$ & $27,8 \%$ \\
\hline Bekendheid met de taal & $22,8 \%$ & $25,9 \%$ \\
\hline Bekendheid met de cultuur & $10,9 \%$ & $19,4 \%$ \\
\hline Bekendheid met de wet- en regelgeving & $7,9 \%$ & $22,2 \%$ \\
\hline Bekendheid met de omgeving & $6,9 \%$ & $10,2 \%$ \\
\hline Ik vind deze studentenstad een fijne stad om te werken & $28,7 \%$ & $28,7 \%$ \\
\hline Anders & $12,9 \%$ & $16,7 \%$ \\
\hline
\end{tabular}




\section{Verschillen naar herkomstregio en opleidingssector}

In de vorige paragraaf werden de totaaluitkomsten voor de Zuyd Hogeschool en de Universiteit Maastricht beschreven. Het ligt echter voor de hand dat de patronen anders zijn voor verschillende deelpopulaties binnen deze twee instellingen. In het bijzonder kunnen voor afgestudeerden die zelf uit de regio komen andere factoren van belang zijn dan voor afgestudeerden die van elders zijn gekomen om in Zuid-Limburg te studeren. Bovendien kunnen afgestudeerden van verschillende studierichtingen ook andere beweegredenen hebben om in de stad te blijven werken, of om juist om elders werk aan te nemen. In deze paragraaf geven we hier een beeld van, door de punten aan te geven waar groepen van afgestudeerden significant afwijken van het totaalbeeld van elk van de onderwijsinstellingen.

\subsection{Verschillen naar herkomstregio}

We kijken eerst naar de mate waarin de keuze om wel of niet in de studiestad te blijven werken verschilt naar herkomstregio. We maken hierbij onderscheid tussen mensen die al op 16-jarige leeftijd in de provincie Limburg woonden en mensen die toen elders woonden. We zien een groot verschil tussen Zuyd Hogeschool, waarvan zo'n $73 \%$ van de afgestudeerden uit Limburg kwam, en Universiteit Maastricht, waarvan slechts $25 \%$ op 16-jarige leeftijd in de provincie woonde. De resultaten laten zien dat afgestudeerden die op 16-jarige leeftijd al in Limburg woonden significant vaker in de studiestad werken dan afgestudeerden die elders vandaan komen. Dit verschil is vooral groot onder afgestudeerden van de UM, waarvan 34\% van de afgestudeerden die uit Limburg kwamen in Maastricht zijn blijven werken, tegenover slechts $11 \%$ van de afgestudeerden die van buiten Limburg naar Maastricht kwamen. We zien een beduidend minder groot verschil onder afgestudeerden van Zuyd, waar 16\% van de afgestudeerden uit de regio in de studiestad is blijven werken, tegenover $9 \%$ van de afgestudeerden die van buiten Limburg afkomstig waren.

Andere opvallende resultaten voor afgestudeerden van Zuyd Hogeschool zijn:

- Afgestudeerden die van buiten Limburg afkomstig zijn:

o vinden netwerkactiviteiten, careerevents en bestuursactiviteiten tijdens de studie relatief vaak goede manieren om de interesse werk in de studiestad te vergroten;

o werken vaak in een andere stad vanwege de werksituatie van de partner, relaties met familie en vrienden, onbekendheid met de taal, cultuur en wet- en regelgeving en de wens om de eigen horizon te verbreden; blijven vaker in de studiestad 
werken vanwege de werksituatie van de partner en omdat ze de studiestad een fijne stad vinden om te werken;

- Afgestudeerden uit Limburg afkomstig:

o noemen relatief vaak de band met familie en vrienden en de intentie vooraf om in de regio te blijven waar men is opgegroeid als redenen om in de studiestad te blijven werken.

Opvallende resultaten voor afgestudeerden van Universiteit Maastricht zijn:

- Afgestudeerden die van buiten Limburg afkomstig zijn:

o vinden netwerkactiviteiten en careerevents tijdens de studie vaker goede manieren om de interesse in werken in de studiestad te vergroten;

o blijven vaker in de studiestad werken vanwege betere baankansen en de werksituatie van de partner;

o werken vaker buiten de studiestad vanwege de relaties met familie en vrienden, de onbekendheid met de taal, cultuur en wet- en regelgeving, en de mening dat Maastricht geen fijne stad is.

- Afgestudeerden uit Limburg afkomstig:

o geven vaker aan dat hun interesse om in Maastricht te blijven is vergroot door de informatie die is ontvangen tijdens de studie over de regionale werkgelegenheid:

o noemen relatief vaak de band met familie en vrienden, de intentie vooraf om in de regio te blijven waar men is opgegroeid, en bekendheid met de omgeving als redenen om in de studiestad te blijven werken.

\subsection{Verschillen naar opleidingssector}

We kijken vervolgens naar de mate waarin de keuze om wel of niet in de studiestad te blijven werken verschilt naar opleidingssector. Bij Zuyd Hogeschool zien we relatief veel afgestudeerden die in de studiestad zijn blijven werken in de sectoren kunst (30\%) en bètatechniek (20\%). Bij de Universiteit Maastricht is dit percentage relatief hoog onder afgestudeerden van de sectoren gezondheidszorg (20\%) en economie (18\%).

Andere opvallende resultaten voor afgestudeerden van Zuyd zijn:

- Afgestudeerden van de sector gezondheidszorg:

o noemen vaak netwerkactiviteiten en vrijwilligerswerk tijdens de studie als goede manieren om de interesse in werk in de studiestad te vergroten;

o werken relatief vaak buiten de studiestad vanwege de intentie om terug te gaan naar de regio van herkomst, de werksituatie van de partner, relaties met familie en vrienden, onbekendheid met de taal, cultuur en wet- en regelgeving en de mening dat de studiestad geen fijne stad is om in te werken;

- Afgestudeerden van de sector economie:

o noemen vaker netwerkactiviteiten, careerevents en bestuursactiviteiten tijdens de studie als goede manieren om de interesse om te werken in de studiestad te vergroten; 
- Afgestudeerden van de sector kunst:

o noemen onderzoek en/of opdrachten voor bedrijven en organisaties en bestuursactiviteiten tijdens de studie relatief vaak als factoren die hun interesse hebben vergroot om in de studiestad te blijven werken;

o werken relatief vaak buiten de studiestad vanwege een verschil in cultuur en de wens om de eigen horizon te verbreden;

- Afgestudeerden van de sector bètatechniek:

o noemen onderzoek en/of opdrachten voor bedrijven en organisaties tijdens de studie relatief vaak als goede manieren om de interesse om te werken in de studiestad te vergroten.

Andere opvallende resultaten voor UM-afgestudeerden zijn:

- Afgestudeerden van de sector economie:

o noemen onderzoek en/of opdrachten voor bedrijven en organisaties tijdens de studie relatief vaak als activiteit die hun interesse hebben vergroot om in de studiestad te blijven werken;

o noemen careerevents tijdens de studie relatief vaak als goede manier om de interesse in het werken in de studiestad te vergroten;

o werken relatief vaak buiten de studiestad vanwege betere baankansen elders en onbekendheid met wet- en regelgeving;

- Afgestudeerden van de sector gedrag en maatschappij:

o noemen informatie over werkgelegenheid, onderzoek en/of opdrachten voor bedrijven en organisaties, netwerkactiviteiten en vrijwilligerswerk tijdens de studie relatief vaak als goede manieren om de interesse in een baan in de studiestad te vergroten;

o werken relatief vaak buiten de studiestad vanwege de intentie om terug te gaan naar de regio van herkomst, en door een ervaren taalbarrière;

- Afgestudeerden van de sector gezondheidszorg:

o werken relatief vaak buiten de stad vanwege de intentie om terug te gaan naar de regio van herkomst, door relaties met familie en vrienden en door een ervaren verschil in cultuur;

- Afgestudeerden van de sector recht:

o kiezen relatief vaak om in de studiestad te blijven werken vanwege de werksituatie van de partner, de bekendheid met de cultuur en de bekendheid met de wet- en regelgeving.

\subsection{Verschillen naar studiestad (alleen voor Zuyd Hogeschool)}

De resultaten laten zien dat afgestudeerden uit de locatie Sittard-Geleen van Zuyd Hogeschool significant minder vaak in de studiestad werken (11\%) dan afgestudeerden uit de locaties Heerlen en Maastricht (beiden 16\%). 
Andere opvallende resultaten zijn:

- netwerkactiviteiten, careerevents en bestuursactiviteiten tijdens de studie worden significant vaker genoemd als goede manieren om de interesse in werk in de studiestad te vergroten onder afgestudeerden uit Maastricht, en significant minder vaak door afgestudeerden uit Sittard-Geleen;

- de keuze om in een andere de stad gaan werken hangt significant vaker samen met de onbekendheid met wet- en regelgeving en met de mening dat de studiestad geen fijne stad is om te werken wanneer men in Heerlen is afgestudeerd; onder afgestudeerden uit Maastricht worden de intentie om terug te gaan naar de regio van oorsprong, de werksituatie van de partner, de band met familie en vrienden, en de wens om de eigen horizon te verbreden vaak genoemd als redenen om elders te gaan werken;

- afgestudeerden uit Maastricht noemen relatief vaak het feit dat ze Maastricht een fijne stad vinden om te werken als reden om in de studiestad te blijven werken; afgestudeerden uit Sittard-Geleen noemen relatief vaak de band met familie en vrienden en de bekendheid met de wet-en regelgeving als reden om te blijven werken in hun studiestad. 


\section{Conclusie}

De resultaten uit dit rapport zijn gebaseerd op een enquête die eind 2020 is uitgezet onder hbo- en wo-afgestudeerden van Zuyd Hogeschool en Universiteit Maastricht om te onderzoeken of en waarom schoolverlaters al dan niet in dezelfde stad werkzaam zijn als waar ze hebben gestudeerd.

Slechts een klein deel van de afgestudeerden besloot te blijven werken in de stad waar ze hebben gestudeerd. Dit percentage is een veel hoger onder afgestudeerden die op 16-jarige leeftijd al in Limburg woonden, vooral onder afgestudeerden van de UM. Dit percentage bleek ook te verschillen naar opleidingssector, waarbij afgestudeerden van de sector economie aan Zuyd hogeschool, en afgestudeerden van de sectoren gedrag en maatschappij en rechten aan de UM geografisch het meest mobiel zijn en dus het vaakst gaan werken in een andere stad.

Studenten die nog in hun studiestad werken gaven aan dat vooral stages hun interesse hierin had vergroot. Andere activiteiten, zoals informatie over werkgelegenheid, onderzoek en/of opdrachten voor bedrijven en organisaties en netwerkactiviteiten werden vaker genoemd door afgestudeerden van Universiteit Maastricht dan door afgestudeerden van Zuyd Hogeschool. Een grote meerderheid van afgestudeerden van de UM gaf aan dat hun voorkeur niet was veranderd door de aangeboden activiteiten. De afgestudeerden van de UM hebben wel vaker hun voorkeur veranderd dan de afgestudeerden van Zuyd.

Ook onder afgestudeerden die niet in de studiestad zijn blijven werken zien we dat UM-afgestudeerden meer geneigd zijn dan afgestudeerden van Zuyd om te denken dat allerlei activiteiten van invloed kunnen zijn op de keuze om in de studiestad te blijven werken. Vooral stages, informatie over beschikbare werkgelegenheid, onderzoek of opdrachten voor bedrijven en organisaties, netwerkactiviteiten en careerevents worden als kansrijke acties gezien om de interesse van studenten te vergroten om in hun studiestad te blijven werken.

Op de vraag naar de redenen waarom afgestudeerden niet in de studiestad zijn blijven werken, worden betere baankansen elders het vaakst genoemd, gevolgd door het feit dat velen al van tevoren de intentie hadden om terug te gaan naar de regio waar ze voorafgaand aan de opleiding woonden. Een aantal afgestudeerden gaf aan dat het besluit met hun privésituatie te maken had, en met de persoonlijke banden in de regio waar ze naartoe zijn verhuisd. Vooral voor de afgestudeerden aan de UM blijkt sprake te zijn van een taalbarrière, 
wat waarschijnlijk te maken heeft met het feit dat de UM over het algemeen meer internationale afgestudeerden aantrekt.

Onder afgestudeerden die besloten wel in de studiestad te blijven werken, bleken de baankansen minder vaak als reden te zijn genoemd, en lijkt het meer een kwestie van de band die men met de regio voelt. Ongeveer drie op de tien afgestudeerden gaf aan dat ze van tevoren al de intentie had om te blijven studeren en werken in de regio waar ze zijn opgegroeid, en ook de aanwezigheid van familie en vrienden in de regio en bekendheid met de omgeving werden vaak belangrijk gevonden. Vooral voor afgestudeerden van de UM komt daar nog bij dat hun partner in de regio werkt, en dat ze bekend zijn met de plaatselijke taal en cultuur.

De invloed van activiteiten en de genoemde redenen om wel of niet elders werk te zoeken verschillen vaak naar herkomstregio, opleidingssector, en voor Zuyd Hogeschool naar studiestad. Over het algemeen lijkt het besluit van afgestudeerden die van buiten Limburg zijn gekomen om hier te komen studeren, sterker samen te hangen met ervaringen die ze tijdens de studie hebben opgedaan en met specifieke kenmerken van hun professionele en privéleven. Ze lijken meer ontvankelijk voor activiteiten zoals netwerkactiviteiten, careerevents en bestuursactiviteiten tijdens de studie als mogelijke manieren om hen meer aan de studiestad te binden. Tegelijkertijd blijken ze relatief vaak elders te gaan werken vanwege de werksituatie van de partner, relaties met familie en vrienden. Ook blijven ze vaker in de studiestad werken vanwege de werksituatie van de partner en vanwege hun eigen baankansen. Afgestudeerden uit Limburg blijven relatief vaak in de studiestad vanwege de band met familie en vrienden, en met de intentie vooraf om in de regio te blijven waar men is opgegroeid.

Voor afgestudeerden van economische opleidingen lijkt het besluit om wel of niet te blijven vaak een relatief zakelijke kwestie. Ze lijken gevoelig te zijn voor allerlei activiteiten tijdens de studie zoals netwerk- en careeractiviteiten, en baseren hun keuze relatief vaak op baankansen. Voor afgestudeerden van gezondheidszorgopleidingen lijken zakelijke overwegingen gemengd te zijn met meer maatschappelijke en persoonlijke overwegingen. Zo lijken ze ontvankelijk te zijn voor activiteiten zoals vrijwilligerswerk tijdens de studie, en baseren ze hun feitelijke mobiliteitsbesluit vaak op zaken als banden met familie en vrienden en de mate waarin ze in de regio zijn ingebed. Afgestudeerden van de sectoren kunst en bètatechniek van Zuyd Hogeschool geven aan vaak gevoelig te zijn voor opdrachten voor plaatselijke bedrijven of organisaties, wat een manier kan zijn om hun interesse om te blijven in de studiestad positief te beïnvloeden. Afgestudeerden van de sector gedrag en maatschappij van de UM lijken in veel opzichten op afgestudeerden van gezondheidszorgopleidingen, in de zin dat ze zakelijke overwegingen combineren met maatschappelijke en persoonlijke overwegingen.

Er blijken ten slotte wat verschillen te zijn tussen de verschillende locaties van Zuyd Hogeschool. Zo lijken afgestudeerden uit de stad Maastricht relatief ontvankelijk te zijn voor netwerk- en careeractiviteiten tijdens de studie, en hun feitelijke keuzes vaak te baseren op de band die ze met de stad al hadden en/of tijdens de studie hebben opgebouwd. Afgestudeerden uit de stad Heerlen nemen relatief vaak een baan elders aan door onbekendheid met wet- en regelgeving van de studiestad en de mening dat de studiestad geen fijne 
stad is om te werken. Afgestudeerden uit Sittard-Geleen lijken weinig ontvankelijk voor ervaringen tijdens de studie, en noemen relatief vaak de band met familie en vrienden en de bekendheid met de wet- en regelgeving als reden om te blijven werken in hun studiestad. 



\section{Literatuur}

Cörvers, F. (2019). De regionale arbeidsmarkten van het Randland: eenheid in verscheidenheid. In Land in Samenhang: Krimp en regionale kansengelijkheid (pp. 88-110). Rijksoverheid. https://www.rijksoverheid.nl/documenten/rapporten/2019/10/31/landin-samenhang---krimp-en-regionale-kansengelijkheid

De Hoon, M., \& Cörvers, F. (2016). Literatuuronderzoek ten behoeve van Caribisch Nederland. Push-en pullfactoren bij werving, selectie en behoud van leraren in afgelegen gebieden. ROA. ROA Technical Reports No. 001 https://doi.org/10.26481/umarot.2016001

Fielding, A.J. (1992). Migration and social mobility: South East England as an escalator region. Regional Studies, Vol. 26, No. 1, pp. 1-15. https://doi.org/10.1080/00343409212331 346741

Harris, J.R. and Todaro, M.P. (1970). Migration, unemployment, and development: A two-sector analysis. American Economic Review, Vol. 60, No. 1, pp. 126-142. http://www. sciepub.com/reference/99877

Hooijen, l., \& Cörvers, F. (2019). Vestiging en vertrek in gemeente Maastricht: Studenten en afgestudeerden. ROA. ROA Reports No. 003 https://doi.org/10.26481/umarep.2019003

Meier, S., D. van der Wouw en N. Reverda (2015). Randland. Rooilijn, Themanummer Randland, Vol. 48, No. 4, pp. 272-279.

Williams, J.D., en Sofranko, A.J. (1979). Motivations for the inmigration component of population turnaround in nonmetropolitan areas. Demography, Vol. 16, No. 2, pp. 239-255. https://pubmed.ncbi.nlm.nih.gov/456704/ 
